\title{
PENINGKATAN HASIL BELAJAR SISWA KELAS V PADA MATA PELAJARAN IPA DI SD NEGERI KAWANGKOAN KECAMATAN KALAWAT
}

\author{
Kosmas Sobon \& Sofly Junike Lumowa \\ ksobon@unikadelasalle.ac.id, soflylumowa@gmail.com \\ Pendidikan Guru Sekolah Dasar \\ Fakultas Ilmu Pendidikan \\ Universitas Katolik De La Salle Manado
}

\begin{abstract}
The purpose of this research is to increase student activity and learning outcomes in science learning in fifth grade. This research is a classroom action research conducted in two cycles. Each cycle consists of two learning meetings. The subject of this research is the fifth grader at the state elementary school of kawangkoan. Data collection techniques use tests, observations and documentation. The results showed that: (1) student learning activity in first cycle is $72,50 \%$ with active criterion and on second cycle is $76,15 \%$ with active criterion; (2) mastery of student learning outcomes in first cycle is $71,43 \%$ and second cycle is $100 \%$. Based on these results, it can be concluded that by the method of demonstration can improve the quality of learning science subjects, that is: student activity and student learning outcomes of fifth grade state elementary school Kawangkoan.
\end{abstract}

Keywords: demonstration methods, science, learning activity, learning result

\begin{abstract}
Abstrak : Tujuan dari penelitian ini adalah untuk meningkatkan aktivitas dan hasil belajar siswa dalam pembelajaran sains di kelas lima SD. Penelitian ini merupakan penelitian tindakan kelas yang dilakukan dalam dua siklus. Setiap siklus terdiri dari dua pertemuan. Subyek penelitian ini adalah siswa kelas lima SD Negeri Kawangkoan. Teknik pengumpulan data menggunakan tes, observasi dan dokumentasi. Hasil penelitian menunjukkan bahwa: (1) aktivitas belajar siswa pada siklus I sebesar $72,50 \%$ dengan kriteria aktif dan pada siklus II sebesar $76,15 \%$ dengan kriteria aktif; (2) ketuntasan hasil belajar siswa pada siklus I sebesar 71,43\% dan siklus kedua $100 \%$. Berdasarkan hasil tersebut, dapat disimpulkan bahwa dengan metode demonstrasi dapat meningkatkan kualitas pembelajaran mata pelajaran sains, yaitu: aktivitas siswa dan hasil belajar siswa kelas lima SD Negeri Kawangkoan.
\end{abstract}

Kata Kunci: metode demonstrasi, IPA, aktivitas belajar, hasil belajar.

\section{PENDAHULUAN}

Kualitas pendidikan sangat memengaruhi tingkat sumber daya manusia dalam sebuah bangsa. Pendidikan yang berkualitas merupakan salah satu indikator sebuah bangsa yang maju. "Pendidikan merupakan suatu proses dalam rangka mempengaruhi siswa agar dapat menyesuaikan diri sebaik mungkin terhadap lingkungannya yang akan 
Kosmas \& Sofly, Penggunaan Metode Demonstrasi untuk...

menimbulkan perubahan dalam dirinya sehingga dapat berfungsi dalam kehidupan bermasyarakat" (Cahyo, 2013:17). Konsep pendidikan pada dasarnya membuat siswa memiliki kompetensi tamatan sesuai jenjang sekolah, yaitu pengetahuan, nilai, sikap, dan kemampuan melaksanakan tugas atau mempunyai kemampuan untuk mendekatkan dirinya dengan lingkungan alam, lingkungan sosial, lingkungan budaya, dan kebutuhan daerah. Sementara itu, kondisi pendidikan di negara kita dewasa ini, lebih diwarnai oleh pendekatan yang menitikberatkan pada model belajar konvensional seperti ceramah sehingga kurang mampu merangsang siswa untuk terlibat aktif dalam proses belajar mengajar. Suasana belajar seperti itu, semakin menjauhkan peran pendidikan dalam upaya mempersiapkan warga negara yang baik dan masyarakat yang cerdas (Djahiri, 1993:45)

Sekolah adalah tempat pendidikan formal untuk meletakan dasar-dasar pendidikan. Artinya, lewat pendidikan dasar peserta didik diberikan pemahaman tentang konsep-konsep dasar seperti membaca, menghitung, dan menulis. Sekolah dasar merupakan salah satu lembaga pendidikan formal di Indonesia yang bertujuan untuk meningkatkan konsep-konsep dasar bagi dunia pendidikan. Menurut Mirasa (dalam Susanto, 2013:70) "pendidikan dasar sebagai proses pengembangan kemampuan yang paling mendasar setiap siswa, di mana setiap siswa belajar secara aktif karena adanya dorongan dalam diri dan adanya suasana yang memberikan kemudahan (kondusif) bagi perkembangan dirinya secara optimal."

Ada begitu banyak persoalan yang dihadapi dalam sebuah pembelajaran di sekolah. Persoalan tersebut dapat dilihat dari berbagai bidang misalnya: pembangunan fisik sekolah, media pembelajaran, fasilitas pendidikan, proses pembelajaran, kualitas guru dan tenaga administrasi, kepemimpinan sekolah dan sebagainya. Salah satu masalah pendidikan yang masih berkembang dewasa ini adalah lemahnya proses pembelajaran. Pembelajaran yang sering dipakai lebih berorientasi kepada guru sehingga siswa hanya sebagai objek ajar yang terus diberi dengan segudang informasi. Siswa tidak diberi kesempatan untuk menunjukkan eksistensi dirinya guna berpartisipasi dalam pembelajaran. Fenomena seperti ini dapat mengakibatkan menurunnya motivasi berprestasi siswa ketika belajar yang pada akhirnya keberhasilan pembelajaran menjadi berkurang.

Pada hakikatnya, banyak faktor yang dapat mempengaruhi keberhasilan belajar siswa yang dapat dikelompokkan menjadi faktor internal dan eksternal. Salah satu faktor internalnya adalah pengaruh dari dalam diri siswa tersebut baik dilihat dari semangat ataupun motivasi belajarnya, dan salah satu faktor eksternalnya adalah guru. Guru berperan besar dalam menyusun strategi pembelajaran yang menyenangkan dan menarik agar siswa termotivasi untuk berprestasi serta dapat memahami pelajarannya dengan baik. Dalam kegiatan pembelajaran siswa seharusnya berperan sebagai subjek didik, tetapi dalam fenomena kegiatan pembelajaran siswa dianggap sebagai objek didik, siswa diperankan secara aktif untuk menkonstruksi pengetahuan yang didapatkan, 
Kosmas \& Sofly, Penggunaan Metode Demonstrasi untuk...

tidak hanya pasif. Sebagai objek didik, siswa biasanya berada di bawah kekuasaan guru. Guru sebagai pengelola kelas mempunyai wewenang terhadap kelas yang dikelolanya. Siswa mengikuti apa yang diinstruksikan oleh guru, padahal siswa mempunyai hak untuk berpendapat, berinisiatif jika ada hal yang kurang cocok pada diri siswa. Siswa sebagai objek didik juga harus aktif dalam kegiatan pembelajaran sehingga kegiatan pembelajaran berlangsung efektif. Siswa tidak hanya duduk mendengarkan ceramah dari guru ataupun mencatat apa yang tertulis dari papan tulis, tetapi siswa berusaha mencoba menemukan pengetahuannya sendiri dengan bimbingan dari guru, dengan demikian pembelajaran ini berpusat pada diri siswa (student centered) dan hasilnya siswa akan terbiasa bersikap aktif untuk mengkonstruksi pengetahuannya.

Berdasarkan hasil pengamatan pada proses belajar mengajar pada siswa di SD Negeri Kawangkoan Kecamatan Kalawat khususnya khususnya pada siswa kelas V ditemukan bahwa kegiatan proses pembelajaran IPA selama ini masih jauh dari apa yang diharapkan. Pada umumnya kegiatan pembelajaran di sekolah selalu didominasi oleh guru (teacher centered). Dari pengamatan yang didapat terlihat bahwa kondisi siswa dalam menerima pembelajaran materi salat dengan metode ceramah banyak siswa yang ramai dengan teman sebangkunya, ada juga yang tidur di mejanya, bahkan ada yang diam dengan pandangan kosong tidak jelas. Bahkan juga pada umumnya siswa hanyalah menjadi pendengar, pencatat, dan peringkas materi yang ada pada materi buku sumber.

Masalah lain yang ditemukan di kelas adalah guru tidak pernah memberikan kegiatan praktek dalam pembelajaran IPA dengan menggunakan media atau alat-alat peraga sesuai materi ajar supaya siswa lebih mengerti materi yang diajarkan. Guru tidak pernah mendemonstrasikan materi ajar IPA dengan menggunakan bahan/alat yang sederhana dan terjangkau di dalam kelas sehingga siswa lebih mudah mengerti dan memahami lebih baik pembelajaran IPA. Hal ini terbukti dengan hasil belajar IPA kelas $\mathrm{V}$ pada materi sifat-sifat cahaya di mana hanya 33,33\% yang lulus sedangkan yang lain tidak mencapai standar ketuntasan minimal (KKM). Artinya hanya 7 siswa yang mendapat nilai tuntas dari 21 jumlah siswa yang ada. Artinya ada 14 siswa yang belum mencapai nilai KKM.

Berdasarkan hasil belajar dan pengamatan awal tersebut nampak jelas terjadi kesenjangan antara harapan pembelajaran IPA dengan kenyataan yang terjadi di lapangan atau di kelas. Persoalan sekarang adalah bagaimana mencari cara/metode pembelajaran yang baik untuk menyampaikan berbagai konsep IPA yang diajarkan sehingga siswa dapat menggunakan dan mengingat lebih lama konsep tersebut. Salah satu alternatif untuk mengatasi masalah tersebut adalah penerapan metode demonstrasi dalam pembelajaran IPA. Metode demonstrasi merupakan metode yang sederhana untuk mempertunjukkan proses terjadinya suatu peristiwa atau benda sampai pada penampilan tingkah laku yang dicontohkan. Metode demonstrasi dapat mengantar siswa untuk memahami materi ajar yang masih bersifat abstrak dan bersifat teoritis. 
Kosmas \& Sofly, Penggunaan Metode Demonstrasi untuk...

Metode demonstrasi cocok bagi pembelajaran siswa sekolah dasar dalam usia 7 sampai dengan 11 tahun. Pada usia ini siswa belum mampu berpikir secara abstrak, melainkan pembelajaran perlu melibat pengalaman langsung, bentuk konkret dalam upaya mengerti tentang alam sekelilingnya. Penegasan ini sejalan dengan hasil pemikiran Subini (2012:157) yang menegaskana "kemampuan anak pada tahap ini (7-11 tahun) masih dalam bentuk konkret, mereka belum mampu berpikir abstrak, sehingga mereja juga hanya menyelesaikan soal-soal pembelajaran yang bersifat konkret. Aktivitas pembelajaran yang melibatkan siswa dalam pengalaman langsung sangat efektif dibandingkan penjelasan guru dalam bentuk verbal (kata-kata)."

Berdasarkan latar belakang di atas ditemukan bahwa pembelajaran IPA masih menjadi permasahan di SD Negeri Kawangkoan. Oleh karena itu, maka dalam penelitian tindakan kelas ini penulis memilih judul "Penggunaan Metode Demonstrasi untuk Peningkatan Hasil Belajar IPA di Kelas V SD N Kawangkoan Kecamatan Kalawat."

Berdasarkan latar belakang yang telah dikemukakan tersebut, maka pokok permasalahan penelitian dapat dirumuskan sebagai berikut: (1) Bagaimanakah penggunaan metode demonstrasi dalam meningkatkan aktivitas belajar siswa kelas $\mathrm{V}$ pada pembelajaran IPA di SD Negeri Kawangkoan?, (2) Bagaimanakah penggunaan metode demonstrasi dalam meningkatkan hasil belajar siswa pada mata pelajaran IPA di kelas V di SD Negeri Kawangkoan?. Adapun tujuan penelitian tindakan kelas ini adalah: (1) Meningkatan aktivitas belajar siswa di kelas V pada pembelajaran IPA di SD Negeri Kawangkoan, (2) Meningkatan hasil belajar siswa pada mata pelajaran IPA di Kelas V SD Negeri Kawangkoan melalui penerapan metode demonstrasi.

\section{KAJIAN TEORI}

\section{Konsep Metode Demonstrasi}

Demonstrasi merupakan salah satu bentuk metode pembelajaran dalam proses belajar mengajar. Melalui demonstrasi, seorang guru mempertunjukkan materi ajar kepada siswa baik menyangkut fakta, kejadian, maupun konsep-konsep pengetahuan. Secara leksikal, kata 'demonstrasi' berarti peragaan yang dipertunjukkan dengan melakukan suatu cara-cara menerapkan sesuatu, selanjutkan kata 'berdemonstrasi' berarti mengadakan pergaan. Sedangkan kata 'metode' berarti cara sistematis dan berpikir secara baik untuk mencapai tujuan. Metode juga berarti prinsip dan praktekpraktek pengajaran (dalam Fajri dan Aprilia Senja, 2008:565). Selanjutnya menurut Susanto (2013:153) metode secara harafiah diartikan dengan 'cara'. Dalam pemakaian yang umum diartikan sebagai cara melakukan suatu kegiatan atau cara melakukan suatu kegiatan atau cara melakukan pekerjaan dengan menggunakan fakta dan konsep-konsep secara sistematis.

Metode demonstrasi adalah metode penyajian pelajaran dengan memperagakan dan mempertunjukkan kepada siswa tentang suatu proses, situasi atau benda tertentu, 
Kosmas \& Sofly, Penggunaan Metode Demonstrasi untuk...

baik sebenarnya atau hanya sekadar tiruan. Sebagai metode penyajian, demonstrasi tidak terlepas dari penjelasan secara lisan oleh guru. Walaupun dalam proses demonstrasi peran siswa hanya sekadar memperhatikan, akan tetapi demonstrasi dapat menyajikan bahan pelajaran lebih konkret. Dalam strategi pembelajaran, demonstrasi dapat digunakan untuk mendukung keberhasilan strategi ekspositori dan inkuiri.

Berdasarkan beberapa pengertian tersebut, maka dapat disimpulkan bahwa metode demonstrasi merupakan cara atau metode yang digunakan untuk mempertunjukan atau memperagakan materi pelajaran. Dengan mempertunjukan benda atau peristiwa yang sudah dipelajari, maka materi pelajaran akan lebih mudah dipahami oleh siswa. Dengan kata lain, metode demonstrasi bertujuan untuk menjelaskan konsep atau materi yang abstrak. Artinya, metode demonstrasi merupakan yang lebih afektif dalam membantu siswa untuk mencari jawaban/solusi dengan usaha sendiri berasarkan fakta atau data yang benar.

\section{Konsep Hasil Belajar}

Secara sederhana dapat dijelaskan bahwa hasil adalah prestasi dari suatu kegiatan yang telah dikerjakan, diciptakan, baik secara individu maupun kelompok. Hasil tidak akan pernah dihasilkan selama orang tidak melakukan sesuatu. Untuk menghasilkan sebuah prestasi dibutuhkan perjuangan dan pengorbanan yang sangat besar. Belajar menurut Susanto (2013:4) adalah "suatu aktivitas yang dilakukan seseorang dengan sengaja dalam keadaan sadar untuk memperoleh konsep, pemahaman atau pengetahuan baru sehingga memungkinkan seseorang terjadinya perubahan perilaku yang relatif tetap baik dalam berpikir, merasa, maupun dalam bertindak."

Menurut Arikunto (dalam Ekawarna, 2013:70) yang dimaksud dengan "hasil belajar adalah suatu hasil yang diperoleh siswa setelah mengikuti proses pengajaran yang dilakukan oleh guru. Hasil belajar ini biasanya dinyatakan dalam bentuk angka, huruf, atau kata-kata baik, sedang, kurang dan sebagainya." Begitu pula menurut Hamalik (dalam Ekawarna, 2013:70) "hasil belajar adalah perubahan tingkah laku pada diri siswa, yang dapat diamati dan diukur dalam bentuk perubahan pengetahuan, sikap, dan keterampilan."

Dari beberapa konsep tersebutkan dapat ditegaskan bahwa hasil belajar merupakan hasil dari suatu interaksi tindak belajar dan tindak mengajar. Dari sisi guru, tindak mengajar diakhiri dengan proses evaluasi hasil belajar. Dari sisi siswa, hasil belajar merupakan berakhirnya pengajaran dari puncak proses belajar. dengan kata lain hasil belajar adalah sebuah parameter tingkat keberhasilan proses belajar yang ditunjukkan oleh besaran angka yang didapatkan dalam kegiatan ujian, dan juga perubahan tingkah laku yang terjadi dari seorang siswa.

Selanjutnya menurut Wasliman (dalam Susanto, 2013:13) "sekolah merupakan salah satu faktor yang ikut menentukan hasil belajar siswa. Semakin tinggi kemampuan belajar siswa dan kaulitas pengajaran di sekolah, maka semakin tinggi pula hasil belajar siswa." 
Kosmas \& Sofly, Penggunaan Metode Demonstrasi untuk...

Pendapat yang senada juga dikemukakan oleh Ruseffendi (dalam Susanto, 2013:14) yang "mengidentifikasi faktor-faktor yang mempengaruhi hasil belajar ke dalam sepuluh macam, yaitu kecerdasan, kesiapan anak, bakat anak, kemauan belajar, minat anak, model penyajian materi, pribadi dan sikap guru, suasana belajar, kompetensi guru, dan kondisi masyarakat." Hal ini sejalan dengan apa yang dikatakan oleh Sudjana (dalam Susanto, 2013:15) bahwa "hasil belajar yang dicapai oleh siswa dipengaruhi oleh dua faktor utama, yaitu faktor dalam diri siswa dan faktor yang datang dari luar diri siswa atau faktor lingkungan."

Berdasarkan uraian tersebut, nampak jelas bawah faktor-faktor yang mempengaruhi hasil belajar siswa dapat dilihat dari faktor internal dan dari faktor eksternal. Faktor intern adalah faktor yang ada dalam diri individu yang sedang belajar, sedangkan faktor ekstern adalah faktor yang ada di luar individu.

\section{Konsep Ilmu Pengetahuan Alam}

Haryono (2013:42-43) menjelaskan: "IPA adalah pengetahuan yang telah diuji kebenarannya melalui metode ilmiah. IPA berhubungan dengan cara mencari tahu tentang alam secara sistematis, sehingga IPA bukan hnya penguasaan kumpulan pengetahuan yang berupa fakta-fakta, konsep-konsep, atau prinsip-prinsip saja tetapi juga merupakan suatu proses penemuan."

Pembelajaran IPA perlu didesain dengan baik sehingga dapat menyentu kehidupan kongkrit peserta didik. Oleh karena itu, kegiatan-kegiatan pembelajaran IPA pada sekolah dasar sebaiknya dilakukan melalui diskusi, percobaan, simulasi, dan kegiatan proyek di lapangan. Pengembangan sikap ilmiah di sekolah dasar memiliki kesesuaian dengan tingkat perkembangan kognitifnya. Hal ini sesuai dengan penegasan dari Piaget (dalam Susanto, 2012:170) yakni: anak usia 11 atau 12 tahun masuk dalam kategori fase operasional konkret. Fase yang menunjukkan adanya sikap keingintahuannya cukup tinggi untuk mengenali lingkungannya. Dalam kaitannya dengan tujuan pendidikan IPA, maka pada anak sekolah dasar siswa harus diberikan pengalaman serta kesempatan untuk mengembangkan kemampuan berpikir dan bersikap terhadap alam, sehingga dapat mengetahui rahasia dan gejala-gejala alam.”

\section{Hubungan Metode Demonstrasi dengan Proses Belajar IPA}

Dalam kaitannya dengan pembelajaran IPA di kelas, metode demonstrasi adalah suatu cara atau bentuk penyajian materi pembelajaran yang lebih kongkrit. Hal yang sama diungkapkan oleh Hamruni (2012:7) bahwa "dalam kaitannya dengan pembelajaran, metode didefinisikan sebagai cara-cara menyajikan bahan pelajaran pada peserta didik untuk tercapainya tujuan yang telah ditetapkan. Jadi secara singkat, metode demonstrasi adalah suatu cara mengajar, cara sistematis dengan mempertunjukan cara kerja suatu benda." Artinya metode demonstrasi dapat merangsang pikiran, perasaan, perhatian dan minat peserta didik sehingga terjadi proses belajar IPA. Secara sederhana melalui metode demonstrasi dalam pembelajaran IPA ada nilai-nilai praktis yang diperoleh yaitu: (1) metode demonstrasi memungkinkan adanya 
Kosmas \& Sofly, Penggunaan Metode Demonstrasi untuk...

interaksi antara peserta didik dengan lingkungannya; (2) secara potensial, metode demonstrasi yang dipertunjukkan secara tepat dapat menanampkan konsep dasar IPA yang konkret, benar dan berpijak pada realitaa; (3) metode demonstrasi dapat membangkitkan keinginan, minat baru, dan motivasi serta merangsang peserta didik untuk belajar IPA; dan (4) metode demonstrasi memberikan belajar secara integral dan menyeluruh.

Berdasarkan penjelasan di atas maka dapat disimpulkan bahwa metode demonstrasi dapat meningkatkan dan mempertinggi proses belajar peserta didi yang pada akirnya dapat meningkatkan hasil belajar peserta didik. Metode demonstrasi memiliki hubungan yang sangat erat dengan proses pembelajaran IPA, di mana siswa lebih banyak melakukan kegiatan belajar karena tidak hanya mendengarkan uraian guru, tetapi juga aktivitas lain seperti mengamati, melakukan, mendemonstrasikan, dan lainlain. Dengan kata lain, melalui metode demonstrasi pembelajaran IPA di kelas menjadi lebih konkret, lebih mudah dan sesuai dengan permasalahan kehidupan yang dihadapi oleh peserta didik.

\section{METODE}

Metode yang digunakan dalam penelitian ini adalah Penelitian Tindakan Kelas (PTK). Arikunto (dalam Ekawarna, 2013:5) menegaskan "penelitian tindakan kelas adalah suatu kegiatan yang dilakukan oleh guru atau bersama-sama dengan orang lain (kolaborasi) yang bertujuan untuk memperbaiki atau meningkatkan mutu proses pembelajaran di kelasnya."

Penelitian Tindakan Kelas ini dilaksanakan di SD Negeri Kawangkoan Kecamatan Kalawat khusus pada kelas V. Penelitian ini dilaksanakan pada bulan September sampai Oktober 2017. Penelitian ini juga dilaksanakan dalam dua siklus. Setiap siklus dilaksanakan dalam 2 kali pertemuan. Setiap siklus itu dibuat untuk melihat dan mengukur kemampuan dan pemahaman siswa pada materi IPA setelah melaksanakan dan mengimplementasikan metode demonstrasi.

Subjek penelitian ini adalah siswa kelas V SD Negeri Kawangkoan Kecamatan Kalawat. Jumlah siswa adalah 21 siswa yang terdiri 8 siswa laki-laki dan 13 siswa perempuan dan guru kelas $\mathrm{V}$ sekaligus sebagai peneliti, dengan mata pelajaran Ilmu Pengetahuan IPA.

\section{HASIL PENELITIAN \\ Deskripsi Pra Siklus}

Pada bagian ini akan dijelaskan data-data yang diperoleh sebelum pelaksanaan penelitian. Artinya peneliti mendeskripsikan data hasil belajar siswa kelas V SD Negeri Kawangkoan sebelum pelaksanaan siklus I. Dalam latar belakang sebelumnya telah dijelaskan bahwa data hasil observasi awal yang dilaksanakan oleh peneliti dalam pembelajaran IPA pada siswa kelas V SD Negeri Kawangkoan Kecamatan Kalawat 
Kosmas \& Sofly, Penggunaan Metode Demonstrasi untuk...

menunjukan bahwa masih banyak siswa yang mendapat nilai di bawah Kriteria Ketuntasan Minimum (KKM) yang ditetapkan yaitu 75. Dari 21 siswa yang ada hanya 6 siswa yang mendapat nilai tuntas (mendapat nilai di atas 75) dengan nilai tertinggi adalah 80 sedangkan sebagian besar siswa lainnya mendapat nilai di bawah kriteria ketuntasan berjumlah 15 siswa dengan nilai paling rendah adalah 45. Dengan kata lain kurang lebih 33,33\% saja siswa yang mendapat hasil belajar yang baik sedangkan $66,67 \%$ lainnya tidak lulus dan harus melakukan kegiatan pengulangan materi. Dengan melihat hasil belajar siswa tersebut, maka perlu untuk ditingkatkan kualitasnya. Salah satu cara untuk meningkatkan hasil belajar siswa tersebut adalah melalui penerapan suatu metode pembelajaran. metode yang dipilih untuk maksud tersebut adalah metode demonstrasi pada pembelajaran IPA di kelas V.

\section{Siklus I}

Dengan melihat data hasil belajar siswa pada mata pelajaran IPA melalui metode demonstrasi pada siklus I maka dapat diperoleh data sebagai berikut:

\section{Tabel 1. Hasil Belajar Siklus 1}

\begin{tabular}{|c|l|c|}
\hline No & \multicolumn{1}{|c|}{ Aspek } & Pencapaian \\
\hline 1 & Nilai Rata-rata yang dicapai & 74.76 \\
\hline 2 & Nilai terendah & 56 \\
\hline 3 & Nilai tertinggi & 89 \\
\hline 4 & Jumlah siswa tuntas & 15 \\
\hline 5 & Jumlah siswa tidak tuntas & 6 \\
\hline
\end{tabular}

Berdasarkan tabel hasil belajar tersebut nampak jelas bahwa hasil belajar siklus 1 belum memenuhi KKM. Hal ini dapat ditemukan bahwa terdapat 15 siswa yang tuntas dan 6 siswa yang belum tuntas dengan nilai rata-rata seluruh siswa dari 21 siswa yang mengikuti ujian yakni 74.76. adapun nilai yang paling rendah adalah 56 dan nilai yang tertinggi adalah 89 .

Dengan demikian persentase hasil belajar siswa pada siklus I dapat dilihat dalam diagram berikut ini:

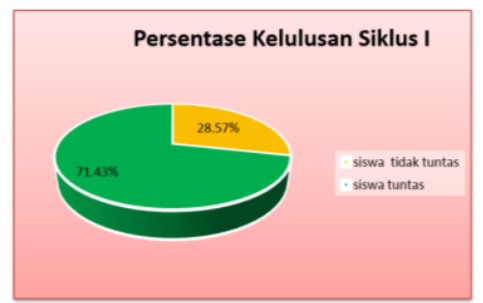

\section{Diagram 1. Persentase Kululusan Siklus 1}

Berdasarkan diagram di atas dapat diketahui bahwa persentase ketuntasan hasil belajar pada siklus I sebesar $71.57 \%$ atau 15 siswa yang tuntas, sedangkan siswa yang tidak tuntas sebesar $28.57 \%$ atau 6 siswa yang belum tuntas. Dengan kata lain terjadi peningkatan $38.24 \% \%$ ketuntasan hasil belajar siswa bila dibandingkan sebelum penerapan metode demonstrasi pada pembelajaran IPA di kelas V. 
Kosmas \& Sofly, Penggunaan Metode Demonstrasi untuk...

\section{Siklus II}

Dengan melihat data hasil belajar siswa pada mata pelajaran IPA melalui metode demonstrasi pada siklus I maka dapat diperoleh data sebagai berikut:

Tabel 1. Hasil Belajar Siklus 2

\begin{tabular}{|c|l|c|}
\hline No & \multicolumn{1}{|c|}{ Aspek } & Pencapaian \\
\hline 1 & Nilai Rata-rata yang dicapai & 82.42 \\
\hline 2 & Nilai terendah & 75 \\
\hline 3 & Nilai tertinggi & 96 \\
\hline 4 & Jumlah siswa tuntas & 21 \\
\hline 5 & Jumlah siswa tidak tuntas & 0 \\
\hline
\end{tabular}

Berdasarkan tabel hasil belajar tersebut nampak jelas bahwa hasil belajar siklus II telah memenuhi KKM yakni 75 nilai rata-rata. Hal ini dapat ditemukan bahwa terdapat 21 siswa yang tuntas atau tuntas semua dengan nilai rata-rata seluruh siswa dari 21 siswa yang mengikuti ujian yakni 82,42. adapun nilai yang paling rendah adalah 75 dan nilai yang tertinggi adalah 96.

Dengan demikian persentase hasil belajar siswa pada siklus I dapat dilihat dalam diagram berikut ini:

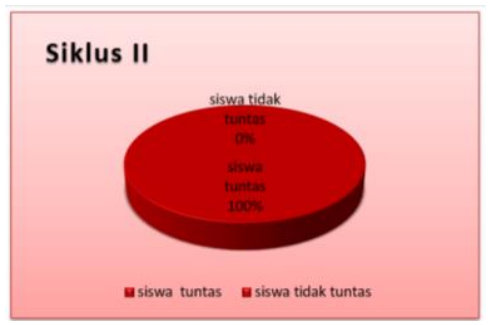

\section{Diagram 2. Persentase Kululusan Siklus 2}

Berdasarkan diagram di atas dapat diketahui bahwa persentase ketuntasan hasil belajar pada siklus II sebesar $100 \%$ atau 21 siswa yang tuntas, sedangkan siswa yang tidak tuntas sebesar $0 \%$ atau semua siswa tuntas, dengan kata lain terjadi peningkatan $28.57 \%$ ketuntasan hasil belajar siswa bila dibandingkan dengan hasil belajar dalam siklus I, yakni dari 71.43\% (Siklus I) meningkat menjadi 100\% (Siklus II).

\section{Rekapitulasi Data Sikus I dan II}

Rekapitulasi data siklus I dan siklus II dapat disajikan dalam bentuk diagram sebagai berikut:

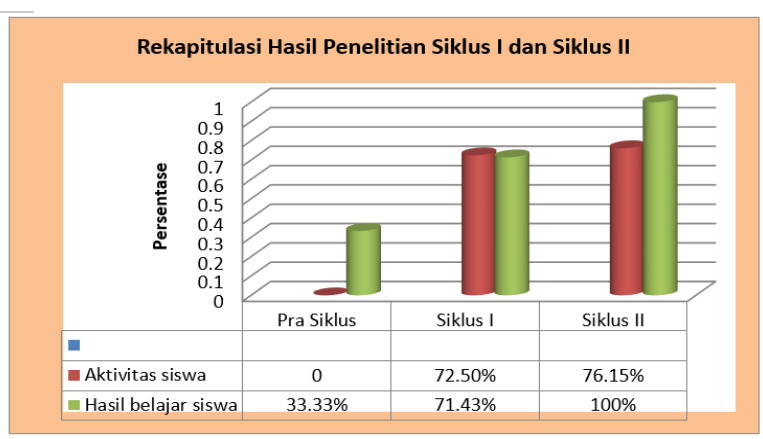

Grafik 1. Rekapitulasi Data Sikus I dan II 
Kosmas \& Sofly, Penggunaan Metode Demonstrasi untuk...

Berdasarkan diagram tersebut dapat dilihat adanya peningkatan aktivitas belajar siswa dari siklus I ke siklus II. Persentase aktivitas siswa siklus I 72.5\% dan siklus II 76.15\%. Begitu pun dalam hasil belajar siswa terjadi peningkatan dari pra siklus ke siklus I dan ke siklus II. Persentase hasil belajar pra siklus 33,33\%, siklus $71.43 \%$ dan siklus II $100 \%$.

\section{PEMBAHASAN}

\section{Aktivitas Siswa}

Aktivitas belajar siswa merupakan salah satu indikator penting dalam penelitian ini. Artinya salah satu tujuan dari penelitian ini adalah untuk mengukut tingkat aktivitas belajar siswa di kelas V saat mengikuti proses pembelajaran di SD. Hasil penelitian untuk mengukur observasi aktivitas siswa diperoleh melalui lembar observasi yang berisi delapan indikator yang diamati oleh guru. Delapan indikator tersebut adalah: 1) Perhatian dan ketenangan dalam mengikuti pembelajaran; 2) Antusiasme mengikuti penjelasan materi oleh guru; 3) Tingkat pemahaman kelompok atas langkah-langkah metode demonstrasi; 4) Tingkat keaktifan siswa dalam pelaksanaan metode demonstrasi; 5) Kemampuan dalam bekerja sama; 6) Suasana dan antusiasme dalam mengerjakan soal tes; 7) Hasil laporan kelompok tentang hasil demonstrasi; 8) Keaktifan dalam bertanya dan menanggapi;

Hasil observasi aktivitas siswa dengan bertitik tolak pada delapan indikator tersebut diperoleh ketika proses pembelajaran IPA dengan menggunakan metode demonstrasi berlangsung. Delapan indikator aktivitas siswa yang dinilai tersebut senada dengan apa yang diungkapkan oleh Sardiman (Wawan, 2010:12) bahwa "aktivitas dalam proses belajar mengajar adalah rangkaian kegiatan yang meliputi keaktifan siswa dalam mengikuti pelajaran, bertanya hal yang belum jelas, mencatat, mendengar, berpikir, membaca dan segala kegiatan yang dilakukan yang dapat menunjang prestasi belajar." Selanjutnya, Kunandar (2012:277) menegaskan: "Indikator aktivitas belajar dapat dilihat dari: pertama, mayoritas siswa beraktivitas dalam pembelajaran; kedua, aktivitas pembelajaran didominasi oleh kegiatan siswa; ketiga, mayoritas siswa mampu mengerjakan tugas yang diberikan guru."

Hasil penelitian menunjukan bahwa aktivitas siswa terjadi peningkatan dari siklus I ke siklus II. Pada siklus I aktivitas siswa mencapai $72.5 \%$ dan pada siklus II meningkat menjadi $76.15 \%$. Artinya terjadi peningkatan $4 \%$ aktivitas siswa dari siklus I ke siklus II. Peningkatan yang aktivitas siswa sangat nampak jelas pada siklus II. Salah satu indikasi yang membuat aktivitas siswa meningkat adalah siswa mulai tahap demi tahap mengerti tentang metode demonstrasi dan menyenanginya.

Khusus pada siklus II pada materi "Cahaya putih terdiri dari berbagai warna," aktivitas siswa ini mulai mengarahkan pada penemuan sendiri atas masalah-masalah yang dialami sehari-hari, misalnya siswa mulai mampu menguraikan peristiwa cahaya dalam kehidupan sehari. Contoh kongkrit peristiwa pelangi. Peserta didik mulai terarah 
Kosmas \& Sofly, Penggunaan Metode Demonstrasi untuk...

pemikiran mereka pada hal-hal kongkrit atas kehidupan lingkungan sehari-hari. Hal ini sesuai dengan pendapat Dierich (dalam Hamalik, 2010:172) bahwa "Mental activities, seperti menanggap, mengingat, memecahkan soal, menganalisis, melihat hubungan, mengambil keputusan."

Berdasarkan uraian pembahasan di atas dapat dismpulkan penggunaan metode demonstrasi dapat meningkatkan aktivitas siswa pada pembelajaran IPA pada siswa kelas V SD Negeri Kawangkoan. Artinya melalui metode demonstrasi di sekolah, siswa diajarkan untuk belajar hidup sosial, bekerja sama, saling membantu, saling memotivasi dan saling menghormati.

\section{Hasil Belajar siswa}

Instrumen yang dipakai untuk mengukur ketuntasan siswa melalui tes tertulis pada saat setiap pembelajaran selesai. Dari data yang ada menunjukkan bawah peningkatan hasil belajar dari pelaksanaan pra siklus ke siklus I sebesar $38.1 \%$ sedangkan dari siklus I ke siklus II hasil belajar meningkat menjadi 28.57\%. Dengan kata lain hasil belajar siswa terjadi peningkatan dari pra siklus ke siklus I dan ke siklus II.

Dengan melihat data-data yang ada ketuntasan belajar klasikal melalui penggunaan metode demonstrasi pada pembelajaran IPA kelas V SD Negeri Kawangkoan telah sesuai dengan target yang direncanakan. Pada indikator keberhasilan pencapaian ketuntasan belajar maksimal 75\% dan pada siklus II diperoleh $100 \%$ berarti penelitian sudah berhasil pada siklus II.

Secara lebih jelas peningkatan hasil belajar IPA melalui penerapan pembelajaran metode demonstrasi dapat disajikan dalam diagram di bawah ini:

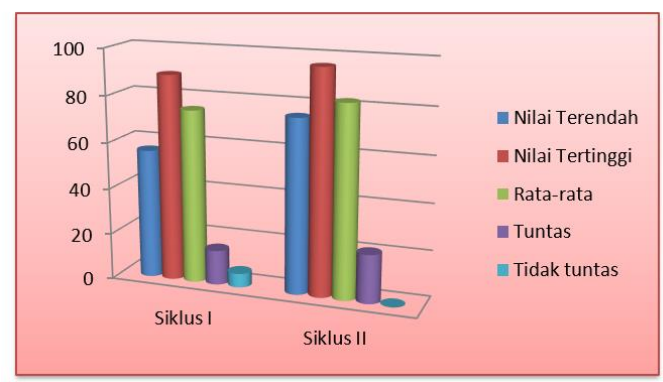

Grafik 2. Rekapitulasi Hasil Belajar Siswa Sikus I dan II

Dengan demikian, penelitian tindakan kelas dengan tahapan siklus dihentikan karena peningkatan ketrampilan guru,aktivitas siswa, dan hasil belajar siswa telah memenuhi target yakni sesuai KKM (Kriteria Ketuntasan Minimal) 75.

\section{SIMPULAN}

Berdasarkan hasil observasi belajar siswa dan hasil belajar siswa dalam pembelajaran IPA melalui penggunaan metode demonstrasi pada siswa kelas V SD Negeri Kawangkoan dan pembahasan yang sudah dikemukakan maka dapat 
Kosmas \& Sofly, Penggunaan Metode Demonstrasi untuk...

disimpulkan: (1) Aktivitas belajar siswa melalui penggunaan metode demonstrasi pada mata pelajaran IPA mengalami peningkatan. Aktivitas belajar siswa pada siklus I mencapai persentase $72.5 \%$ dengan kriteria aktif. Pada siklus II mencapai persentase $76.15 \%$ masuk dalam kriteria aktif, (2) Pembelajaran IPA melalui penggunaan metode demonstrasi di kelas V SD Negeri Kawangkoan dapat meningkatkan hasil belajar siswa. Hal ini ditunjukkan dengan persentase ketuntasan hasil belajar siswa pada siklus I $71.43 \%$ dan siklus II $100 \%$. Selanjutnya jumlah siswa yang tuntas dalam siklus I adalah 15 orang, tidak tuntas 6 orang dan dalam siklus II semua siswa tuntas.

\section{SARAN}

1. Menggunakan metode demonstrasi siswa terdorong untuk dapat berperan aktif dan berani mengemukakan pendapatnya serta mendemonstrasikan materi ajar sehingga peserta didik lain dapat mengerti dengan baik.

2. Hendaknya guru mempertimbangkan penggunaan metode demonstrasi dalam pembelajaran IPA supaya siswa memahami dengan baik isi materi yang didemonnstrasikan di depan kelas.

\section{DAFTAR PUSTAKA}

Cahyo N. Agus. 2012. Panduan Apliikasi Teori-Teori Belajar-Mengajar Teraktual dan Terpopuler. Yogyakarta: Diva Press.

Djahiri, (1993).Landasan falsafah dan teori teknologi pendidikan, Media Kencana, IKIP Jakarta

Ekawarna. 2013. Penelitian Tindakan Kelas, Edisi Revisi. Jakarta: Referensi GP Press Group.

Hamruni. 2012. Strategi Pembelajaran. Yogyakarta: Insan Madani.

Haryono. 2013. Pembelajaran IPA yang Menarik dan Mengasyikkan: Teori dan Aplikasi PAIKEM. Yogyakarta: Kepel Press.

Hamalik, Oemar. 2010. Proses Belajar Mengajar. Jakarta: Pustaka Setia

Kunandar. 2012. Langkah Mudah Penelitian Tindakan Kelas sebagai Pengembangan Profesi Guru. Jakarta: PT. Rajagrafindo Persada.

Subini, Nini, dkk. 2010. Psikologi Pembelajaran. Yogyakarta: Mentari Pustaka.

Susanto, Ahmad. 2013. Teori Belajar \& Pembelajaran di Sekolah Dasar. Jakarta: Kencana Prenada Media Group. 